\title{
Profiling of Drug-Metabolizing Enzymes and Transporters in Human Tissue Biopsy Samples: A Review of the Literature ${ }^{[\mathbf{s}}$
}

\author{
A. David Rodrigues and Andrew Rowland \\ ADME Sciences, Medicine Design, Worldwide Research \& Development, Pfizer Inc., Groton, Connecticut (D.R.) and College of \\ Medicine and Public Health, Flinders University, Adelaide, Australia (A.R.)
}

Received October 1, 2019; accepted December 19, 2019

\begin{abstract}
Within the drug pharmacokinetics (PK)-absorption, distribution, metabolism, and excretion (ADME) research community, investigators regularly generate in vitro data sets using appropriately vendor-sourced and processed human tissue. Such data enable drug screening, the generation of kinetic parameters, extrapolation of in vitro to in vivo, as well as the modeling and simulation of drug PK. Although there are large numbers of manuscripts describing studies with deceased organ donor tissue, relatively few investigators have published studies utilizing living donor tissue biopsy samples. After a review of the available literature, it was possible to find publications describing the use of tissue biopsy samples to determine enzyme inhibition ex vivo, the study of genotype-phenotype associations, the evaluation of tissue expression profiling following an inducer, and assessment of correlations between tissue expression profiles and in vivo-derived trait measures (e.g., biomarker plasma levels and probe drug PK). Some reports described multiple single-tissue biopsies, whereas others described single multiple-organ biopsies. It is concluded that biopsy-derived data can support modeling exercises (as input data and when validating models) and enable the
\end{abstract}

assessment of organ-specific changes in enzyme and transporter profiles resulting from drug interactions, disease (e.g., metabolic disease, fibrosis, inflammation, cancer, infection), age, pregnancy, organ impairment, and genotype. With the emergence of multiorgan axes (e.g., microbiome-gut-liverkidney) and interest in remote sensing (interorgan communication), it is envisioned that there will be increased demand for single- and multiorgan tissue biopsy data to support hypothesis testing and PK-ADME model building.

\section{SIGNIFICANCE STATEMENT}

Based on a review of the literature, it is apparent that profiling of human tissue biopsy samples is useful in support of pharmacokinetics (PK)-absorption, distribution, metabolism, and excretion (ADME)-related studies. With conventional tissue biopsy as precedent, it is envisioned that researchers will turn to less invasive "liquid biopsy" methods in support of ADME-related studies (e.g., profiling of plasma-derived tissue-specific nanovesicles). Generation of such multiorgan liquid biopsy data in larger numbers of subjects and at multiple study time points will provide a rich data set for modeling purposes.

\section{Introduction}

In general, the various processes governing the pharmacokinetics (PK)-absorption, distribution, metabolism, and excretion (ADME) profiles of drugs and various endogenous compounds are very complex and dynamic and often involve multiple organs, such as the gut and liver (Rodrigues and Rowland, 2019). For example, drug interactions can be complicated by a subject's genotype, age, and disease state and involve the complex interplay of drug-metabolizing enzymes and transporters. Even drug interactions involving

https://doi.org/10.1124/jpet.119.262972.

S This article has supplemental material available at jpet.aspetjournals.org. a single enzyme, such as cytochrome P450 (CYP) 3A4, can manifest in the gut and liver and present multiple (mixed) mechanisms involving induction, reversible inhibition, and mechanism-based inhibition. This has galvanized the development of complex, physiologically based PK (PBPK) models, which require increased amounts of input data, and has fostered a greater appreciation for the importance of drug interaction time courses (e.g., time to onset vs. washout) and the timing of victim drug dosing (vs. perpetrator drug).

For the most part, investigators have leveraged in vitro-derived kinetic (substrate and inhibition) data to support in vitro-to-in vivo extrapolations by utilizing vendorprovided human whole cells (e.g., cryopreserved primary hepatocytes) and subcellular tissue fractions (e.g., human

ABBREVIATIONS: A33, antigen 33; ABC, ATP-binding cassette; ADME, absorption, distribution, metabolism, and excretion; AUC, area under the plasma concentration versus time curve; BCRP, breast cancer resistance protein; CYP, cytochrome P450; $\mathrm{E}_{\text {max }}$, maximal induction; miR, microRNA; MRP, multidrug resistance-associated protein; NASH, nonalcoholic steatohepatitis; NCE, new chemical entity; OATP, organic anion transporting polypeptide; PBPK, physiologically based PK; Pgp, P-glycoprotein; PK, pharmacokinetics; SLC, solute carrier; UGT, UDP-glucuronosyltransferase. 
liver microsomes). Such in vitro-to-in vivo extrapolation exercises have supported the modeling and prediction of PK, drug interactions, and intersubject variability. Typically, human whole tissue is obtained from consented single- or multiorgan donors who are deceased (Fig. 1). More recently, increased efforts have focused on the development of plateand chip-based single- and multiorgan human microphysiological systems (Maass et al., 2017; Wang et al., 2018). Such systems have garnered the attention of numerous investigators who have grown to appreciate the need to mimic tissue architecture, dynamic multicell type interactions, multiorgan interactions, as well as the supply of nutrients, oxygen, and drug substrate under flow conditions.

The approaches described above are patently different from those instances in which live study subjects have preconsented to a single- or multiple-tissue biopsy procedure in support of drug-metabolizing enzyme and transporter profiling (Lefor and Flowers, 1994; Padoin et al., 2006; Otuya et al., 2018). Alternatively, some investigators have profiled frozen (banked) tissue biopsy samples (Supplemental Fig. 1) obtained from subjects who had previously undergone endoscopic, laparoscopic, or open surgery (e.g., bariatric surgery, gall bladder surgery, organ transplant, or the excision of tumor tissue and adjacent nontumor tissue) or had required biopsy as part of their diagnosis [e.g., ulcerative colitis, nonalcoholic steatohepatitis (NASH), Rotor syndrome, Crohn disease, Dubin-Johnson syndrome, and drug-induced liver injury].

\section{Advantages, Disadvantages, and Challenges of Tissue Biopsy}

As summarized in Table 1, one of the major advantages of the tissue biopsy approach is that one can dose a subject with

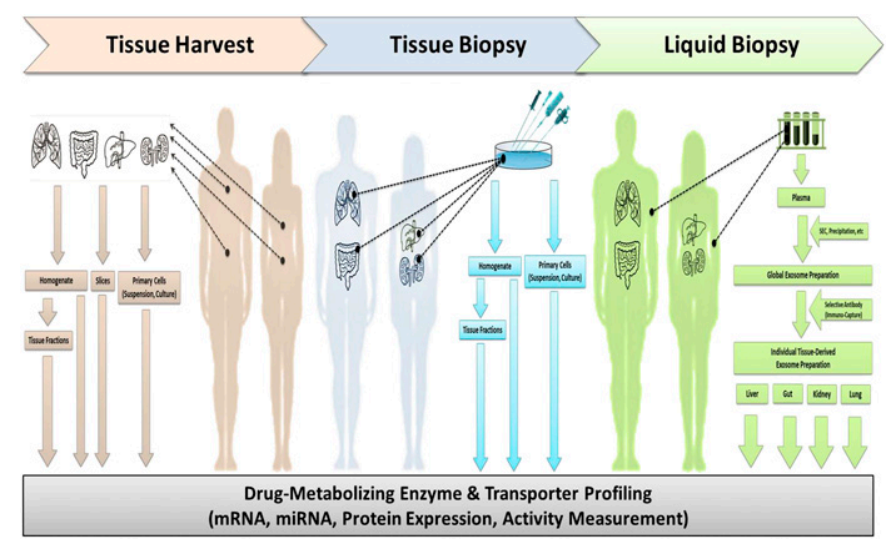

Fig. 1. Summary of approaches to obtain human tissue for the support of drug-metabolizing enzyme and transporter profiling. Tissue harvest involves the removal of the entire organ from the donor (usually deceased), and the samples are processed for the preparation of cultured primary cells and various subcellular fractions to support profiling (e.g., mRNA and protein expression, drug-metabolizing enzyme activity). Tissue biopsy involves obtaining a piece of tissue from a live donor (e.g., during surgery or via a scope-guided procedure). With enough sample, it is possible to obtain preparations of whole cells or derive subcellular fractions for profiling. Liquid biopsy involves the isolation of nanovesicles (exosomes) from blood. In this instance, human blood-derived plasma is subjected to a global exosome isolation procedure [e.g., size exclusion chromatography (SEC) or precipitation]. The preparation of global exosomes can be profiled directly or further subjected to immunocapture protocols that render tissue-selective exosomes for profiling. a drug, obtain the tissue biopsy, and prepare whole cells and subcellular fractions (e.g., cytosol, 9000g supernatant fraction, microsomes). Thereafter, it is possible to generate an ex vivo drug-metabolizing enzyme and transporter messenger ribonucleic acid (mRNA), microRNA ( $\mathrm{miR}$ ), and protein expression profile or measure enzyme activity (after the addition of substrate and cofactor) to establish an ex vivo-to-in vivo extrapolation (Supplemental Fig. 1).

Once generated, biopsy data can be integrated with PK data from the same (biopsied) subject or other study subjects to support PBPK modeling. As discussed in the following sections, there are examples of published reports describing biopsy data to assess CYP3A4 inhibition after dosing of a mechanism-based inhibitor drug, modeling of rifampicin autoinduction by considering the induction of P-glycoprotein (Pgp), and studying the impact of CYP3A5 genotype on PK (Mouly et al., 2005; Zhang et al., 2009; Quinney et al., 2010; Hanke et al., 2018). There are also examples of publications describing the use of tissue biopsy data to rationalize the scaling factors used in PBPK modeling, the study of drugmetabolizing enzyme tissue expression versus plasma-based trait measures (e.g., CYP3A erythromycin breath test and $4 \beta$-hydroxycholesterol), and efforts to simply garner mechanistic insight regarding an observed drug interaction (Lown et al., 1994; Greiner et al.,1999; Westphal et al., 2000; Giessmann et al., 2004b; Marschall et al., 2005; Brueck et al., 2019; Yamazaki et al., 2019). Given the utility of tissue biopsy approaches in support of PK-ADME-related studies, therefore, we sought to review the literature and summarize the findings of exemplar manuscripts. Of the publications reviewed, a few are summarized in tabular form (Tables 2-5), and only some are described in more detail. Although largely focused on gut and liver biopsy, we were aware of publications describing ADME gene and protein expression profiling of skin, lung, and kidney biopsy samples (Thum et al., 2006; Joy et al., 2007; Osman-Ponchet et al., 2014; Krogstad et al., 2018).

As with any method or approach, there are downsides when attempting to include tissue biopsy in protocols. In most cases, such protocols require extensive vetting by institutional review boards and a clear rationale articulated in the accompanying informed consent documentation (Table 1). This is particularly true when studying drug interactions in normal healthy volunteers, deploying such subjects as controls (e.g., vs. diseased, organ-impaired, pediatric, or aged subjects), and when a study necessitates single (multiple tissue) or more than one (single tissue) biopsy. Investigators may also be limited by the amount of tissue that can be obtained in a biopsy, so they assume that such samples are reflective of the target organ as a whole. Investigators may also be challenged by the number of subjects that can be biopsied or have consented to be biopsied. As described in the following, many studies included less than a dozen subjects, and investigators have assumed that the data obtained from a small study apply to a larger and more heterogenous population of subjects.

\section{Tissue Biopsy to Support the Study of Drug-Metabolizing Enzyme and Transporter Induction}

In various tissues, the expression of drug-metabolizing enzymes and transporters is known to be under the regulation 
TABLE 1

Advantages, disadvantages, and challenges of conventional tissue biopsy compared with emerging liquid biopsy approaches

\begin{tabular}{|c|c|c|}
\hline Biopsy Type & Advantages & Disadvantages/Challenges \\
\hline \multirow[t]{4}{*}{$\begin{array}{l}\text { Conventional biopsy (e.g., scope- } \\
\text { guided pinch or needle tissue } \\
\text { biopsy) }\end{array}$} & $\begin{array}{l}\text { Direct assessment of drug-metabolizing enzyme and } \\
\text { transporter expression in target tissue of interest } \\
\text { (mRNA and proteomics) in vivo (e.g., following } \\
\text { administration of inducer drug) }\end{array}$ & $\begin{array}{l}\text { Requires invasive procedure to obtain tissue, robust } \\
\text { study subject consent, and more extensive } \\
\text { institutional review board approval (especially for } \\
\text { normal healthy volunteers) }\end{array}$ \\
\hline & $\begin{array}{l}\text { With adequate sample size, one can prepare subcellular } \\
\text { fractions to support activity assessment }\end{array}$ & $\begin{array}{l}\text { Often limited to one organ site for biopsy and need to } \\
\text { assume that sample is representative of whole organ }\end{array}$ \\
\hline & $\begin{array}{l}\text { Able to correlate biopsy data with trait measures in the } \\
\text { same subject (e.g., drug probe and/or biomarker PK) }\end{array}$ & $\begin{array}{l}\text { Studies involving multiple (single tissue) and single } \\
\text { (multiple organ) biopsies can be challenging to } \\
\text { approve (especially normal healthy volunteers) }\end{array}$ \\
\hline & $\begin{array}{l}\text { Able to leverage biopsy-derived data as input to support } \\
\text { modeling and simulation (e.g., model validation or } \\
\text { input to support prediction) }\end{array}$ & $\begin{array}{l}\text { Often only able to biopsy a small set of study subjects } \\
(N \leq 10) \text {; size of tissue sample may limit } \\
\text { characterization }\end{array}$ \\
\hline \multirow[t]{4}{*}{$\begin{array}{l}\text { Liquid biopsy (e.g., extracellular } \\
\text { vesicles isolated from human } \\
\text { urine or blood) }\end{array}$} & $\begin{array}{l}\text { Leverages readily obtained body fluids; considered } \\
\text { "noninvasive" and supports more straightforward } \\
\text { study subject consent language and institutional } \\
\text { review board approval }\end{array}$ & $\begin{array}{l}\text { Methods for the isolation, storage and handling of } \\
\text { global and tissue-specific blood- and urine-derived } \\
\text { extracellular vesicles are not widely known within } \\
\text { the PK-ADME community and require validation }\end{array}$ \\
\hline & $\begin{array}{l}\text { Can obtain liquid biopsy at multiple time points in } \\
\text { a study and assess time course to support modeling } \\
\text { and simulation exercises }\end{array}$ & $\begin{array}{l}\text { How populations of circulating and urinary } \\
\text { extracellular vesicles turnover, their composition, } \\
\text { and how both relate to the tissue of origin is not } \\
\text { known }\end{array}$ \\
\hline & $\begin{array}{l}\text { Can more readily obtain liquid biopsy from subjects that } \\
\text { are not normal healthy volunteers (e.g., pediatric, } \\
\text { diseased, organ impaired, pregnant) }\end{array}$ & $\begin{array}{l}\text { How liquid biopsy-derived data are used as input for } \\
\text { modeling, and simulation exercises are not well } \\
\text { developed or validated }\end{array}$ \\
\hline & $\begin{array}{l}\text { Can obtain liquid biopsy from larger numbers of } \\
\text { subjects to support more robust statistical analyses }\end{array}$ & \\
\hline
\end{tabular}

of nuclear hormone receptors, cytokines, transcription factors, miRs, and epigenetic factors (Rodrigues and Rowland, 2019). Therefore, it is recognized that drugs can bring about interactions involving the repression or induction of gene expression, and in vitro studies with plated human primary hepatocytes are now routinely conducted to support the generation of different parameters (e.g., maximal induction, $\mathrm{E}_{\max }$; and the concentration rendering half-maximal induction, $\mathrm{EC}_{50}$ ) as input for modeling and simulation exercises (Guo et al., 2013; Almond et al., 2016). Beyond primary hepatocytes, some investigators have performed in vitro induction studies with different intestinal cell lines (e.g., Caco-2, LS180, LS174T, and T84) as enterocyte surrogates (Aiba et al., 2005; Oscarson et al., 2007; Haslam et al., 2008; Weiss et al., 2009). By contrast, there are few examples of in vitro induction studies using gut and liver tissue slices (Supplemental Table 1), and only recently has the induction of CYP3A by rifampicin in isolated cryopreserved human primary enterocytes been described ( $\mathrm{Li}$ et al., 2018).

A review of the literature has provided numerous examples of induction studies employing a tissue biopsy approach (Table 2). In most cases, subjects have consented to pre- and post-treatment biopsies, whereas some investigators reported data following the single biopsy of parallel groups of subjects (e.g., placebo vs. treatment). Studies have encompassed the dosing of drugs (e.g., rifampicin, carbamazepine, efavirenz, omeprazole), smoking, and the consumption of alcohol, natural products (e.g., curcumin), and chargrilled meat. As summarized in Table 2, changes in drug-metabolizing enzyme and transporter mRNA and protein expression in gut and liver biopsies are usually less than 10 -fold, a dynamic range more consistent with tissue slice data versus the fold-induction values $\left(\mathrm{E}_{\max }\right)$ obtained with isolated and plated primary cells (Supplemental Table 1; Guo et al., 2013; Almond et al., 2016). To some investigators, such a magnitude of change is unanticipated, especially when one considers that the concentration of the inducer in the gut during first pass is likely to be very high compared with pregnane $\mathrm{X}$ receptor or constitutive androstane receptor $\mathrm{EC}_{50}$ values (e.g., $>0.1 \mathrm{mM}$ for rifampicin and carbamazepine) (Brueck et al., 2019). This has implications when attempting to predict induction or complex mixed-mechanism (induction, reversible inhibition, and mechanism-based inhibition) drug interactions with new chemical entities (NCEs).

\section{Rifampicin and Carbamazepine as Inducers}

Profiling of Liver Tissue after Rifampicin. The report by Marschall et al. (2005) is particularly important because it is one of the few examples of liver biopsy following an inducer. The study enrolled 30 healthy patients with gallstones scheduled for cholestectomy, which were randomized to a known pregnane $X$ receptor agonist (rifampicin, $600 \mathrm{mg} / \mathrm{d}$ for 1 week), ursodeoxycholic acid (1 g/d for 3 weeks), or no medication before surgery. A wedge liver biopsy specimen was taken to study the expression of transporters and drug-metabolizing enzymes. As expected, the authors determined that CYP3A4 mRNA was induced (3-fold) by rifampicin, which corresponded to a $247 \%$ increase in plasma $4 \beta$-hydroxycholesterol levels. In contrast, ursodeoxycholic acid did not induce CYP3A4 mRNA, and there was less impact on plasma $4 \beta$-hydroxycholesterol levels ( $38 \%$ increase). Of note, rifampicin induced liver UDPglucuronosyltransferase (UGT) 1A1 (2-fold) and multidrug resistance-associated protein (MRP) 2 ( 2-fold) but did not induce organic anion transporting polypeptide (OATP) 1B1 mRNA. To our knowledge, this is the first study to relate changes in liver (biopsy) CYP3A4 expression to plasma $4 \beta$ hydroxycholesterol in the same subjects and to directly assess the induction of OATP in vivo in human liver.

Profiling of Gut Tissue after Rifampicin and Carbamazepine. We felt that it was important to include the report of Brueck et al. (2019), which appeared online during the 
TABLE 2

Summary of literature examples describing drug-metabolizing enzyme and transporter profiling of human tissue biopsy samples following an inducer

\begin{tabular}{|c|c|c|c|c|c|c|}
\hline Inducer & Dose, mg (days) & Tissue Biopsy & $\begin{array}{c}\text { Fold } \\
\text { Increase }\end{array}$ & Measurement & Target(s) & Reference \\
\hline \multirow[t]{5}{*}{ Rifampicin } & \multirow[t]{5}{*}{$600(7)$} & \multirow[t]{5}{*}{ Liver (pre- vs. post-) } & 1.5 & mRNA & $\mathrm{ABCC} 2$ & \multirow[t]{5}{*}{ Marschall et al., 2005} \\
\hline & & & 2.2 & Protein & MRP2 & \\
\hline & & & 2.0 & mRNA & UGT1A1 & \\
\hline & & & No change & mRNA & SLCO1B1 & \\
\hline & & & 3.0 & mRNA & CYP3A4 & \\
\hline Rifampicin & $600(4)$ & Liver (pre- vs. post-) & 4.9 & Protein & CYP3A4 & Ged et al., 1989 \\
\hline \multirow[t]{5}{*}{ Atorvastatin } & \multirow[t]{5}{*}{$80(30)$} & \multirow[t]{5}{*}{ Liver (treated vs. placebo) } & No change & mRNA & SLCO1B1 & \multirow{5}{*}{$\begin{array}{l}\text { Björkhem-Bergman et al., } \\
2013\end{array}$} \\
\hline & & & 3.0 & mRNA & SLCO2B1 & \\
\hline & & & 2.4 & mRNA & $\mathrm{ABCB} 1$ & \\
\hline & & & 2.2 & mRNA & ABCG2 & \\
\hline & & & No change & mRNA & CYP3A4 & \\
\hline \multirow{2}{*}{ Rifampicin } & \multirow{2}{*}{$600(8)$} & \multirow{2}{*}{ Duodenal (pre- vs. post-) } & 2.0 & mRNA & $\mathrm{ABCC} 2$ & \multirow{2}{*}{ Haenisch et al., 2008} \\
\hline & & & 2.1 & Protein & MRP2 & \\
\hline \multirow[t]{2}{*}{ Rifampicin } & \multirow[t]{2}{*}{$600(9)$} & \multirow[t]{2}{*}{ Duodenal (pre- vs. post-) } & 1.8 & mRNA & $\mathrm{ABCC} 2$ & \multirow[t]{2}{*}{ Fromm et al., 2000} \\
\hline & & & 1.4 & Protein & MRP2 & \\
\hline \multirow[t]{2}{*}{ Rifampicin } & \multirow[t]{2}{*}{$600(7)$} & \multirow[t]{2}{*}{ Duodenal (pre- vs. post-) } & $2.2-4.4$ & Protein & CYP3A4 & Greiner et al., 1999 \\
\hline & & & $1.4-3.5$ & Protein & Pgp & \\
\hline Rifampicin & $600(9)$ & Duodenal (pre- vs. post-) & 2.4 & mRNA & ABCB1 & Westphal et al., 2000 \\
\hline & & & 4.2 & Protein & Pgp & \\
\hline Rifampicin & $600(10)$ & Shed enterocytes (pre- vs. & No change & Protein & CYP2D6 & Glaeser et al., 2005 \\
\hline & & post-) & 2.0 & Protein & CYP2C8 & \\
\hline & & & 1.4 & Protein & CYP2C9 & \\
\hline & & & 2.3 & mRNA & CYP3A4 & \\
\hline & & & 3.3 & Protein & & \\
\hline Rifampicin & $600(9)$ & Duodenal (pre- vs. post-) & 3.0 & mRNA & $\mathrm{ABCB} 1$ & Giessmann et al., 2004b \\
\hline & & & 8.3 & Protein & Pgp & \\
\hline & & & 2.1 & mRNA & $\mathrm{ABCC} 2$ & \\
\hline & & & 5.7 & Protein & MRP2 & \\
\hline Rifampicin & $600(9)$ & Duodenal (pre- vs. post-) & 2.2 & mRNA & CYP3A4 & Oscarson et al., 2007 \\
\hline & & & 2.6 & mRNA & ABCB1 & \\
\hline & & & 2.2 & mRNA & ABCC2 & \\
\hline & & & No change & mRNA & OATPs & \\
\hline Rifampicin & $600(8)$ & Duodenal (pre- vs. post-) & Variable & $\operatorname{miR}$ & Multiple & Brueck et al., 2019 \\
\hline Carbamazepine & $600(14-18)$ & & Variable & $\operatorname{miR}$ & Multiple & \\
\hline Carbamazepine & $600(14-18)$ & Duodenal (pre- vs. post-) & $\begin{array}{l}\text { No change } \\
3.5\end{array}$ & $\begin{array}{l}\text { Protein } \\
\text { mRNA }\end{array}$ & Pgp ABCB1 & Giessmann et al., 2004a \\
\hline & & & 3.5 & Protein & MRP2 & \\
\hline & & & 2.5 & mRNA & ABCC2 & \\
\hline Efavirenz & $400(9)$ & Duodenal (pre- vs. post-) & No change & mRNA & CYP3A4 & Oswald et al., 2012 \\
\hline & & & & mRNA & CYP2B6 & \\
\hline & & & & mRNA & ABCB1 & \\
\hline & & & & mRNA & UGT1A1 & \\
\hline & & & & mRNA & SLCO2B1 & \\
\hline Efavirenz & $200,400(10)$ & Duodenal (pre- vs. post-) & No change & Protein & Pgp & Mouly et al., 2002 \\
\hline & & & & Protein & CYP3A4 & \\
\hline Smoking & $\begin{array}{l}3-30 \text { cigarettes per day } \\
20-60(7)\end{array}$ & $\begin{array}{l}\text { Duodenal (smoking vs. } \\
\text { nonsmoking) }\end{array}$ & 4.5 & Activity $^{a}$ & CYP1A1 & Buchthal et al., 1995 \\
\hline Omeprazole & & Duodenal (pre- vs. post-) & 2.5 & Activity $^{a}$ & & \\
\hline Smoking & Not specified & $\begin{array}{l}\text { Liver (smoking vs. } \\
\text { nonsmoking) }\end{array}$ & 3.3 & Activity $^{a}$ & CYP1A1 & Pelkonen et al., 1986 \\
\hline Curcumin & $4000(30)$ & Rectal (pre- vs. post-) & No change & Protein & $\begin{array}{l}\text { UGT1A10 } \\
\text { UGT2B17 }\end{array}$ & Asher et al., 2016 \\
\hline $\begin{array}{l}\text { Chargrilled meat } \\
\text { diet }\end{array}$ & Grilled beef (7) & Duodenal (day 1,5 , and 12 ) & No change & $\begin{array}{l}\text { Protein/ } \\
\text { mRNA }\end{array}$ & $\begin{array}{l}\text { Pgp } \\
\text { (ABCB1) }\end{array}$ & Fontana et al., 1999 \\
\hline & & & No change & $\begin{array}{l}\text { Protein/ } \\
\text { mRNA }\end{array}$ & CYP3A4 & \\
\hline & & & No change & $\begin{array}{l}\text { Protein/ } \\
\text { mRNA }\end{array}$ & CYP3A5 & \\
\hline & & & Increased & $\begin{array}{l}\text { Protein/ } \\
\text { mRNA }\end{array}$ & CYP1A1 & \\
\hline $\begin{array}{l}\text { Alcohol } \\
\text { consumption }\end{array}$ & Not specified & $\begin{array}{l}\text { Liver (active drinkers vs. } \\
\text { nondrinkers) }\end{array}$ & 2.0 & Protein & CYP2E1 & Perrot et al., 1989 \\
\hline
\end{tabular}

${ }^{a}$ 7-ethoxyresorufin O-deethylase.

writing of this review. The authors leveraged their access to banked duodenal biopsy samples from subjects who had been dosed rifampicin (600 $\mathrm{mg} / \mathrm{d}$ for 8 days) or carbamazepine (600 mg/d for 14-18 days) and reported the impact of each inducer on pregnane $\mathrm{X}$ receptor and constitutive androstane receptor mRNA expression, fold-changes in both mRNA and protein expression for three ATP-binding cassette (ABC) transporters [Pgp, MRP2, and breast cancer resistance protein (BCRP)], and the expression profile of numerous miR species. To our knowledge, this is the first report to describe miR expression profiles in human tissue biopsy samples following an inducer drug. The authors were able to determine 
TABLE 3

Summary of literature examples describing drug-metabolizing enzyme profiling of human tissue biopsy samples following an inhibitor

\begin{tabular}{|c|c|c|c|c|c|c|}
\hline Inhibitor & Dose, mg (days) & Tissue Biopsy & \% Inhibition & Measurement & Target & Reference \\
\hline Clarithromycin & 500 , every $12 \mathrm{~h} \mathrm{(7)}$ & Duodenal (pre- vs. post-) & $\begin{array}{l}\text { No change } \\
74 \%\end{array}$ & $\begin{array}{l}\text { Protein expression } \\
\text { Activity }^{a}\end{array}$ & CYP3A4 & Pinto et al., 2005a \\
\hline Clarithromycin & 500 , every $12 \mathrm{~h}(8)$ & Duodenal (serial) & $\begin{array}{l}\text { No change } \\
64 \%-72 \%\end{array}$ & $\begin{array}{l}\text { Protein expression } \\
\text { Activity }^{a}\end{array}$ & CYP3A4 & Quinney et al., 2013 \\
\hline Diltiazem & 120 , every $12 \mathrm{~h} \mathrm{(7)}$ & Duodenal (placebo vs. treated group) & $\begin{array}{l}\text { No change } \\
\text { No change } \\
62 \%\end{array}$ & $\begin{array}{l}\text { mRNA expression } \\
\text { Protein expression } \\
\text { Activity }^{a}\end{array}$ & CYP3A4 & Pinto et al., 2005b \\
\hline
\end{tabular}

${ }^{a}$ Midazolam 1'-hydroxylase.

that after rifampicin dosing, there was a correlation between Pgp (e.g., vs. miR-485-3p, $r=-0.452, P=0.027$ ) and BCRP (e.g., vs. miR-577, $r=-0.437, P<0.033$ ) protein expression with miR levels. After carbamazepine, a significant correlation was also noted between MRP2 protein and miR26a-5p expression $(r=-0.587, P<0.027)$. The same authors reported a statistically significant (albeit weak) increase in gut OATP2B1 mRNA expression following rifampicin (1.2-fold)

TABLE 4

Summary of literature examples describing drug-metabolizing enzyme and transporter profiling of human tissue biopsy samples to study disease, ontogeny, and genotype-phenotype associations

\begin{tabular}{|c|c|c|c|c|c|}
\hline Study & Tissue Biopsy & Change & Measurement & Target & Reference \\
\hline NASH (vs. normal) & Liver & $\begin{array}{l}\text { 1.5-fold increase } \\
1.4 \text {-fold increase }\end{array}$ & $\begin{array}{l}\text { Protein expression } \\
\text { Activity }^{a} \text {. }\end{array}$ & CYP2E1 & Varela et al., 2008 \\
\hline NASH (vs. normal) & Liver & $69 \%$ decrease & mRNA expression & CYP3A4 & $\begin{array}{l}\text { Woolsey et al., } \\
2015\end{array}$ \\
\hline $\begin{array}{l}\text { Celiac disease (pre/post gluten- } \\
\text { free diet) }\end{array}$ & Jejunum & Increase & Immunostaining & CYP3A4 & Lang et al., 1996 \\
\hline Crohn disease (vs. normal) & Colon & $78 \%$ decrease & Protein expression & $\begin{array}{l}\text { CYP3A4 } \\
\text { Pon }\end{array}$ & Wilson et al., 2019 \\
\hline Cholestatic (vs. normal) & Liver & $\begin{array}{l}49 \% \text { decease } \\
34 \% \text { decrease } \\
41 \% \text { decrease }\end{array}$ & $\begin{array}{l}\text { mRNA expression } \\
\text { mRNA expression } \\
\text { mRNA expression }\end{array}$ & $\begin{array}{l}\text { SLCO1B1 } \\
\text { (OATP2) } \\
\text { ABCB11 } \\
\text { (BSEP) } \\
\text { SLC10A1 } \\
\text { (NTCP) }\end{array}$ & Zollner et al., 2001 \\
\hline Morbid obesity & Jejunum & $\begin{array}{l}\text { Variable } \\
\text { Variable } \\
\text { Variable } \\
\text { Variable }\end{array}$ & Proteomics & $\begin{array}{l}\text { ABC } \\
\text { transporters } \\
\text { SLC } \\
\text { transporters } \\
\text { P450 (various) } \\
\text { UGT (various) }\end{array}$ & $\begin{array}{l}\text { Miyauchi et al., } \\
2016\end{array}$ \\
\hline $\begin{array}{l}\text { Ulcerative colitis (vs. } \\
\text { noninflamed tissue) }\end{array}$ & Rectum and colon & $\begin{array}{l}\text { Varied } \\
\text { Varied } \\
\text { Varied } \\
\text { Varied }\end{array}$ & $\begin{array}{l}\text { Protein/mRNA } \\
\text { expression } \\
\text { Protein/mRNA } \\
\text { expression } \\
\text { Protein/mRNA } \\
\text { expression } \\
\text { Protein/mRNA } \\
\text { expression }\end{array}$ & $\begin{array}{l}\text { SLC (various) } \\
\text { ABC (various) } \\
\text { P450 (various) } \\
\text { UGT (various) }\end{array}$ & $\begin{array}{l}\text { Erdmann et al., } \\
\quad 2019\end{array}$ \\
\hline $\begin{array}{l}\text { Subjects with ulcerative colitis } \\
\text { (vs. normal/control subjects) }\end{array}$ & Rectum and colon & $\begin{array}{l}\sim 70 \% \text { decrease } \\
\quad(\text { vs. control) } \\
\sim 85 \% \text { decrease } \\
\quad \text { (vs. control) } \\
\text { No change }\end{array}$ & $\begin{array}{l}\text { mRNA expression } \\
\text { mRNA expression } \\
\text { mRNA expression }\end{array}$ & $\begin{array}{l}\text { ABCB1 } \\
\text { ABCG2 } \\
\text { ABCC2 }\end{array}$ & $\begin{array}{l}\text { Englund et al., } \\
2007\end{array}$ \\
\hline $\begin{array}{l}\text { Impact of age ( } 1 \text { mo to } 1 \text { yr vs. } 1-6 \\
\text { yr vs. }>6 \text { yr) }\end{array}$ & Duodenal & $\begin{array}{l}\text { Decrease } \\
\text { Decrease } \\
\text { Not significant } \\
\text { Not significant }\end{array}$ & $\begin{array}{l}\text { mRNA expression } \\
\text { mRNA expression } \\
\text { mRNA expression } \\
\text { mRNA expression }\end{array}$ & $\begin{array}{l}\text { CYP3A4 } \\
\text { CYP3A5 } \\
\text { CYP3A7 } \\
\text { ABCB1 }\end{array}$ & $\begin{array}{l}\text { Fakhoury et al., } \\
2005\end{array}$ \\
\hline CYP2D6 genotyped subjects & $\begin{array}{l}\text { Liver (heterozygous } \\
\text { variant vs. wild type) }\end{array}$ & $\begin{array}{l}\geq 66 \% \text { decrease (vs. } \\
\text { wild type) } \\
\geq 91 \% \text { decrease (vs. } \\
\quad \text { wild type) }\end{array}$ & $\begin{array}{l}\text { mRNA expression } \\
\text { Activity }^{b}\end{array}$ & CYP2D6 & $\begin{array}{r}\text { McConnachie } \\
\text { et al., } 2004\end{array}$ \\
\hline $\begin{array}{l}\text { Gut CYP3A5 expression vs. } \\
\text { saquinavir oral clearance }\end{array}$ & Duodenal & $\begin{array}{l}\text { No positive } \\
\text { correlation }\end{array}$ & Protein expression & CYP3A5 & Mouly et al., 2005 \\
\hline $\begin{array}{l}\text { CYP3A expression (vs. } \\
\text { erythromycin breath test) }\end{array}$ & Duodenal & Correlation & $\begin{array}{l}\text { Protein/mRNA } \\
\text { expression } \\
\text { Activity }^{c}\end{array}$ & CYP3A $4 / 5$ & Lown et al., 1994 \\
\hline ABCC2 genotyped subjects & Duodenal & Genotype & $\begin{array}{l}\text { Protein/mRNA } \\
\text { expression }\end{array}$ & ABCC2 & $\begin{array}{l}\text { Haenisch et al., } \\
2008\end{array}$ \\
\hline
\end{tabular}

BSEP, bile salt export pump; NTCP, sodium-taurocholate cotransporting polypeptide; ABCB1 is Pgp; ABCG2 is BCRP; ABCC2 is MRP2.

${ }^{a}$ Chlorzoxazone hydroxylase.

${ }^{b} \mathrm{R}-568$ metabolite (M1) formation.

${ }^{c}$ Midazolam 1'-hydroxylase. 
TABLE 5

Summary of literature examples describing drug-metabolizing enzyme and transporter profiling of multiple-tissue biopsy samples from same subject

\begin{tabular}{|c|c|c|c|}
\hline Multiple (Matched) Tissue Biopsy & Measurement & ADME Target & Reference \\
\hline \multirow[t]{4}{*}{ Duodenum, jejunum, and liver } & Protein expression & Pgp & \multirow{4}{*}{$\begin{array}{l}\text { Von Richter et al., } \\
2004\end{array}$} \\
\hline & Protein expression & CYP3A4 & \\
\hline & Protein expression & CYP3A5 & \\
\hline & Activity & CYP3A & \\
\hline \multirow[t]{2}{*}{ Jejunum and liver } & Genotype & Multiple CYP & \multirow[t]{2}{*}{ Krogstad et al., 2020} \\
\hline & Activity & Multiple CYP & \\
\hline \multirow[t]{3}{*}{ Duodenum, jejunum, ileum, and liver } & Protein expression & Pgp & \multirow[t]{3}{*}{ Ulvestad et al., 2013} \\
\hline & Protein expression & OATP1B1 & \\
\hline & Protein expression & CYP3A4 & \\
\hline $\begin{array}{l}\text { Duodenum, ileum, colon (ascending), colon (transverse), and colon } \\
\text { (descending) }\end{array}$ & mRNA expression & $\begin{array}{l}\text { Multiple SLC } \\
\text { transporters }\end{array}$ & Meier et al., 2007 \\
\hline \multirow[t]{4}{*}{ Ascending vs. sigmoid colon } & $\begin{array}{l}\text { Protein/mRNA } \\
\text { expression }\end{array}$ & CYP3A4 & \multirow[t]{4}{*}{ Bergheim et al., 2005} \\
\hline & $\begin{array}{l}\text { Protein/mRNA } \\
\quad \text { expression }\end{array}$ & CYP3A5 & \\
\hline & $\begin{array}{l}\text { Protein/mRNA } \\
\text { expression }\end{array}$ & CYP2E1 & \\
\hline & $\begin{array}{l}\text { Protein/mRNA } \\
\text { expression }\end{array}$ & CYP2C & \\
\hline
\end{tabular}

and carbamazepine (1.5-fold). Such a result is in reasonable agreement with the results of Oscarson et al. (2007), who reported no OATP induction in duodenal biopsies of seven subjects following rifampicin (data not shown). In the same subjects, gut CYP3A4, Pgp (ABCB1, ABCB1), and MRP2 (ABCC2) mRNA expression was increased ( 2- to 3-fold). Compared with rifampicin, carbamazepine presents as a better inducer of OATPs, as Oscarson et al. (2006) described induction of OATP1B1 ( 1.7-fold), OATP1B3 ( 2-fold), and OATP2B1 ( 1.3-fold) mRNA in the livers of two patients with epilepsy patients treated with the drug. Although some investigators have evoked an $\mathrm{E}_{\max }$ of $\sim 2$ for OATP1B induction by rifampicin to support their PBPK modeling effort, direct evidence for such changes in OATP expression in vivo remains elusive (Marschall et al., 2005; Oscarson et al., 2007; Asaumi et al., 2019; Brueck et al., 2019).

Study of CYP2D6 Induction. Rifampicin is regarded as a pleiotropic inducer (Rae et al., 2001), so it is not surprising that there are numerous reports describing its impact on drugmetabolizing enzyme and transporter expression in human gut and liver (Table 2). However, it appears that not every CYP form is induced. For example, Glaeser et al. (2005) reported no statistically significant induction of CYP2D6 protein in preparations of gut biopsy-derived shed enterocytes following rifampicin dosing; CYP3A4 protein expression was increased (3.3-fold) in the same individuals. Such data are consistent with the results obtained with a humanized mouse model expressing human pregnane X receptor, CYP2D6, and CYP3A4 in the gut and liver (Scheer et al., 2015); following rifampicin, CYP3A4 was induced, but no induction of gut or liver CYP2D6 was evident. Unfortunately, there are no human biopsy data describing the impact of rifampicin or other inducers on CYP2D6 expression in the liver, although in vitro data (e.g., human liver slices with rifampicin) present no induction (Supplemental Table 1). Such results are important, because it is accepted that often-used CYP2D6 phenotyping tools (e.g., dextrorphan-to-dextromethorphan concentration ratio in urine and plasma) are contaminated by CYP3A and changes in metabolite-to-parent ratio after an inducer could be incorrectly ascribed to CYP2D6 (Gorski et al., 1994; Jones et al., 1996; Schmider et al., 1997). Consequently, in the absence of tissue biopsy data, there is no direct clinical evidence for the induction (or repression) of CYP2D6 expression (Pan et al., 2017; Sager et al., 2017). In this regard, Ke et al. (2013) have used a PBPK modeling approach to assess the impact of pregnancy on the PK of various CYP2D6 substrates, including dextromethorphan (e.g., metoprolol and clonidine). They concluded that its expression would have to be induced $\sim 2$-fold to account for the observed changes in PK. Although challenging, tissue biopsy profiling would be the most useful approach to directly determine whether such a 2-fold increase in CYP2D6 expression is evident in pregnant women.

Profiling of Pgp Expression in Gut Biopsies to Reconcile Observed Drug Interaction. We are aware of at least two reports describing Pgp expression profiling of gut biopsies to investigate drug interactions with rifampicin. One study published by Greiner et al. (1999) described the impact of rifampicin on digoxin PK. The authors had hypothesized that concomitant rifampicin therapy may affect digoxin disposition in humans by inducing Pgp. They compared the single-dose PK of digoxin (1 $\mathrm{mg}$ oral and $1 \mathrm{mg}$ intravenous) before and after coadministration of rifampicin $(600 \mathrm{mg} / \mathrm{d}$ for 10 days). Duodenal biopsies were also obtained from each study subject before and after the administration of rifampicin. The investigators described that, although the exposure of digoxin decreased with rifampicin, its renal clearance and half-life were not altered. Importantly, it was shown that rifampicin increased intestinal Pgp protein expression $~ 3.5$ fold. Similarly, Westphal et al. (2000) studied the PK of talinolol before and after coadministration of rifampicin $(600 \mathrm{mg} / \mathrm{d}$ for 9 days). During rifampicin treatment, the areas under the curve of intravenous and oral talinolol were significantly lower $(21 \%$ and $35 \% ; P<0.05)$. In this study, it was also shown that rifampicin treatment resulted in a significant increase in Pgp expression in duodenal biopsies (protein, 4.2-fold; and mRNA, 2.4-fold). Such data are very useful because they can support PBPK modeling. This is exemplified by the recent publication of Yamazaki et al. (2019), who modeled the effect of rifampicin on the PK of four different Pgp substrates (digoxin, talinolol, quinidine, and dabigatran etexilate). The authors obtained scaling factors for their 
in vitro-derived Pgp kinetic data, focused on the maximal rate of flux, to adequately recover the clinically observed results. Consistent with published gut biopsy data, they demonstrated that their model could recover the clinically observed drug interaction with rifampicin if Pgp expression in the gut was induced 3- to 4-fold.

\section{Efavirenz as Inducer}

Reports by Mouly et al. (2002) and Oswald et al. (2012) also illustrate the usefulness of tissue biopsy data to rationalize drug interactions. Both sets of investigators were able to assess efavirenz, a non-nucleoside reverse transcriptase inhibitor for the treatment of human immunodeficiency virus infection, as an inducer and confirmed that its impact on plasma-based PK trait measures was driven by induction of CYP3A4 in the liver and not the intestine. In fact, efavirenz was shown not to induce CYP3A4, CYP2B6, Pgp (ABCB1), OATP2B1 [solute carrier (SLC) O2B1], or UGT1A1 mRNA in duodenal tissue biopsies (Oswald et al., 2012). The exact reason for the observed tissue-specific induction is not known, and for certain NCEs in development, such results could cast doubt on the use of hepatocyte-based in vitro data to predict induction in the gut.

\section{Atorvastatin as Inducer}

Although rifampicin does not appear to induce OATPs in vivo, Björkhem-Bergman et al. (2013) did report that OATP2B1 (SLCO2B1) mRNA was statistically significantly induced (3-fold; $P<0.05$ ) in liver biopsies of subjects receiving atorvastatin ( $80 \mathrm{mg}$ for 4 weeks). In the same study, an $\sim 2$-fold induction of liver Pgp (ABCB1) and BCRP ABCG2) was noted in the absence of induction of OATP1B1 and CYP3A4 mRNA. Interestingly, fluvastatin (20 mg/d for 4 weeks) elicited a relatively minimal effect on hepatic gene expression. The exact mechanism of how atorvastatin brings about induction of hepatic OATP2B1 in vivo is not known and needs confirmation.

\section{Impact of Smoking on CYP1A Tissue Expression}

Tissue biopsy approaches are not limited to the study of drug-metabolizing enzyme or transporter induction by drugs. For example, Pelkonen et al. (1986) and Buchthal et al. (1995) were able to leverage tissue biopsy samples to measure CYP1A-catalyzed 7-ethoxyresorufin $O$-deethylase activity in smokers. Buchthal et al. (1995) obtained duodenal biopsies (20 smokers, 21 nonsmokers, and 10 nonsmokers receiving omeprazole $20-60 \mathrm{mg} / \mathrm{d}$ for at least 1 week) and demonstrated a 4.5-fold and 2.5-fold increase in activity in smokers and omeprazole-dosed nonsmokers, respectively. In agreement, Pelkonen et al. (1986) also reported a 3.3-fold increase in 7-ethoxyresorufin $O$-deethylase activity in the liver biopsies of smokers. Such data complement the results of other studies showing that cigarette smoking induces CYP1A, in addition to CYP1B1, in lungs (Smith et al., 2001; Kim et al., 2004; Thum et al., 2006). Evidently, cigarette smoking induces CYP1A expression and activity in at least three organs.

\section{Tissue Biopsy to Study CYP Inhibition}

CYP3A4 expressed in the intestine and liver is also subjected to inhibition by drug interaction perpetrators. In the past, assessment of CYP3A4 inhibition has involved both intravenous and oral administration of a probe drug (e.g., midazolam) and the measurement of changes in its area under the plasma concentration versus time curve (AUC) or the metabolite-toparent concentration ratio (e.g., 1'-hydroxymidazolam-tomidazolam ratio) in plasma (Gorski et al., 1998). It has been assumed that the clearance of an intravenously dosed probe drug is largely reflective of changes in liver CYP3A4 activity. Therefore, deconvolution of oral versus intravenous probe drug plasma AUC ratios (inhibitor vs. placebo) can provide information regarding the inhibition of intestinal CYP3A4. In this regard, widely used CYP3A biomarkers (e.g., plasma $4 \beta$-hydroxcholesterol and urinary $6 \beta$-hydroxycortisol-tocortisol ratio) may not be useful, and investigators have leveraged a gut biopsy approach (Rodrigues and Rowland, 2019).

Clarithromycin. We are aware of at least three studies describing the biopsy of subjects dosed with a known CYP3A4 inhibitor (Table 3). Two studies described duodenal biopsies obtained pre- and postdosing with clarithromycin $500 \mathrm{mg}$ twice per day for about 1 week (Pinto et al., 2005a; Quinney et al., 2013). In both cases, gut homogenate was prepared, and a decrease (64\%-74\%) in measured midazolam 1'-hydroxylase activity was reported. Clarithromycin is known to be a mechanism-based inhibitor of CYP3A4 and forms a macrolide (CYP-iron-nitrosoalkane) complex with the enzyme. Interestingly, the measured decrease in midazolam 1'-hydroylase activity agreed well with PBPK model-based estimates of CYP3A inhibition in the gut by clarithromycin (Quinney et al., 2010). Presumably the complex was stable enough to survive the tissue biopsy and homogenization process. Both groups also assessed the inhibition of hepatic CYP3A4 by determining the $1^{\prime}$-hydroxymidazolam-to-midazolam concentration ratio in plasma (3 hours) after intravenous midazolam. Of note, clarithromycin had a minimal impact on CYP3A4 protein expression in the gut. In one of the studies (Pinto et al., 2005a), the authors measured the concentration of clarithromycin in the gut homogenate $(0.42-2.4 \mathrm{nmol} / \mathrm{l})$ and serum $(\sim 4 \mu \mathrm{M})$.

Diltiazem. Likewise, Pinto et al. (2005b) studied diltiazem (100 mg twice daily for 7 days), also a CYP3A4 complex former, as a CYP3A4 inhibitor and reported a $62 \%$ decrease in gut biopsy homogenate-mediated midazolam 1 '-hydroylase activity (Table 3). There was no significant impact on gut biopsy CYP3A4 mRNA and protein expression. As in the case of clarithromycin, the authors were able to relate these biopsygenerated data to a PBPK model-based prediction of gut wall CYP3A4 inhibition by diltiazem (Zhang et al., 2009). To date, we are not aware of any reports describing liver biopsy following the administration of agents such as clarithromycin and diltiazem.

\section{Tissue Biopsy to Study the Impact of Disease, Age, and Genotype on the Expression and Activity of Drug-Metabolizing Enzymes and Transporters}

Tissue biopsy samples have also supported various efforts to study the impact of disease on the expression of drugmetabolizing enzymes and transporters; diseases have included ulcerative colitis, obesity, celiac, Crohn, and NASH (Table 4). Although not tabulated, it is worth mentioning that at least two groups have profiled tissue biopsies of 
virus-infected subjects. In the first example, Kis et al. (2016) completed extensive (microarray) gene expression profiling of CYPs, nuclear hormone receptors, SLCs, ABC transporters, and markers of inflammation in jejunal mucosal biopsies of subjects that had been diagnosed as human immunodeficiency virus type 1 positive and were either antiretroviral therapy active (plasma viral load $>5000$ copies per milliliter) or naïve (plasma viral load $<50$ copies per milliliter). The study also encompassed immunohistochemical analysis of CYP3A4, Pgp, BCRP, and MRP2. Similarly, Nakai et al. (2008) were able to characterize the hepatic expression profiles (CYPs, ABC transporters, SLCs, nuclear hormone receptors, and proinflammatory cytokines) of biopsied subjects infected with hepatitis $\mathrm{C}$, who had been subdivided into different stages or fibrosis, and the results were compared with liver tissue of noninfected subjects.

In most cases, investigators have leveraged the availability of tissue resulting from surgery or tissue biopsy as part of direct confirmative diagnosis. Beyond diseased subjects, tissue biopsy has also been deployed to study the effect of age on ADME gene and protein expression, as well as genotype-phenotype associations.

\section{Disease}

Intestine. Miyauchi et al. (2016) were able to apply quantitative (targeted) proteomics based on tandem liquid chromatography-mass spectrometry to determine the expression levels of drug-metabolizing enzymes and transporters in human jejunal tissues excised from morbidly obese subjects during gastric bypass surgery. Protein expression levels of 15 different CYP forms, 10 UGTs, CYP reductase, and 49 transporters were determined. Likewise, Erdmann et al. (2019) obtained gut biopsy specimens from the inflamed and noninflamed tissues of 10 patients with ulcerative colitis as well as colonic control tissues of 10 patients without inflammation. Levels of both protein and mRNA expression were quantified and the authors concluded that some enzymes (e.g., CYP2C9, UGT1A1) and transporters (e.g., monocarboxylate transporter 1, Pgp, and BCRP) were significantly decreased during inflammation. Englund et al. (2007) similarly reported a decrease (vs. normal controls) in BCRP (ABCG2) mRNA in the colon (89\% decrease) and rectal (84\% decrease) biopsies of patients with active ulcerative colitis. Expression of ABCB1 (Pgp) mRNA was also decreased in the colon (78\% decrease) and rectal (66\% decrease) biopsies of the same patients. For both ABC transporters, the decrease in mRNA expression was consistent with protein expression changes (immunoblotting), and the effect was less pronounced in biopsy samples of subjects that were in disease remission. The same authors noted that ABCC2 (MRP2) mRNA expression was not impacted by the disease. Importantly, the authors were able to measure the expression of various proinflammatory cytokines (cluster of differentiation 45 , interleukin $1 \beta$, and interleukin 6 ) in the same biopsy samples and noted that they were markedly elevated ( $\geq 4$-fold) in the patients with active disease versus control subjects and patients under remission. The above findings are consistent with the recently published results of Wilson et al. (2019), who showed that there is a decrease in CYP3A4 $(78 \%)$ and Pgp (85\%) protein expression in colon biopsies of patients with Crohn disease.
Even in the absence of mRNA quantitation and proteomics based on tandem liquid chromatography-mass spectrometry, Lang et al. (1996) were able to use formalin-fixed jejunal biopsy specimens from patients with celiac disease at variable times before and after treatment with a gluten-free diet for immunoperoxidase staining after incubation with antiCYP3A4 antisera. Based on the intensity of staining in individual enterocytes, as well as the total number of enterocytes stained, the authors concluded that patients with celiac disease presented lower intestinal CYP3A immunoreactivity and that treatment with a gluten-free diet is associated with an increase in intestinal CYP3A protein.

Liver. With the increased interest in NASH and its potential impact on the PK-ADME profiles of drugs, we noted the report by Woolsey et al. (2015). The authors examined CYP3A activity in healthy volunteers, as well as subjects with biopsyproven NASH, after oral midazolam and measurement of plasma $4 \beta$-hydroxycholesterol. Biopsied subjects with NASH presented 2.4-fold-higher plasma midazolam levels and a statistically significant $69 \%$ decrease in hepatic CYP3A4 mRNA expression (vs. controls). The same authors also reported that plasma $4 \beta$-hydroxycholesterol was $51 \%$ and $37 \%$ lower (vs. control subjects) in subjects with simple steatosis and NASH, respectively. Collectively, plasma-based trait measures agreed with liver biopsy data in this study.

\section{Ontogeny}

In an extensive investigation, Fakhoury et al. (2005) were able to obtain a total of 59 normal duodenal biopsies from children aged 1 month to 17 years (divided into three groups: 1 month to 1 year, $1-6$ years, and $>6$ years). The authors deployed both immunohistochemistry and mRNA quantification. In this instance, CYP3A protein was detected in all enterocytes in the samples from patients over 6 months of age but not in biopsy samples of younger subjects. Pgp protein was also detectable on the surfaces of the enterocytes. Both CYP3A and Pgp mRNA levels were highly variable, but the authors reported that CYP3A4 and CYP3A5 mRNA levels were high during the first year of life and decreased with age. It was concluded that neonates and infants presented significant expression of CYP3A and Pgp mRNA in the intestine, suggesting a different maturation profile of CYP3A and Pgp with age in the liver versus intestine. The approach is very different from other investigators, who have used tissue from deceased donors (Mooij et al., 2014), and relates to ongoing efforts to more holistically model the oral PK of CYP3A substrates by considering age-related changes in both intestinal and hepatic extraction (Brussee et al., 2018).

\section{Relating Genotype to Phenotype}

It is well established that numerous human CYP forms, such as CYP2D6, CYP2C19, and CYP2C9, are expressed polymorphically, and efforts have focused on relating genotype to its protein expression in the human liver (Weiß et al., 2018). Such efforts are important because the correlation of genotype with plasma-based phenotypic trait measures is not always apparent (Waring, 2020). In this regard, the work of McConnachie et al. (2004) is unique because the authors included tissue biopsy specimens collected from genotyped control subjects with no apparent liver disease. CYP2D6 activity in the homogenized biopsy samples was measured using a novel 
selective high-clearance substrate (R-568 metabolite M1 formation), and the liver samples were genotyped for the six most common CYP2D6 genetic variants $(* 3, * 4, * 5, * 6, * 7$, and $* 8)$. The authors determined that the improved assay sensitivity supported the evaluation of CYP2D6 enzyme activity in a few milligrams of liver tissue collected from the biopsy specimens. This meant that they could determine that CYP2D6 activity was decreased ( $\geq 66 \%$ vs. $n=7 C Y P 2 D 6^{*} 1 / * 1$ subjects) in the livers of four subjects carrying the $* 4$ and/or $* 5$ allele. The same individuals also presented a greater than 90\% decrease in CYP2D6 mRNA expression versus the reference subjects.

\section{Studies Describing Multiorgan Biopsies}

Gut and Liver. Relatively few reports describe subjects undergoing multiple organ biopsies (Table 5). For example, Von Richter et al. (2004) were able to obtain duodenum, proximal jejunum, and liver wedge biopsy specimens from 15 patients undergoing a gastrointestinal operation. Enterocytes were isolated from the intestinal samples. After homogenization, the expression of CYP3A4, CYP3A5, and Pgp in gut and liver was determined. CYP3A5 genotype was also considered, and two subjects $\left(C Y P 3 A 5^{*} 1 / * 3\right)$ expressed quantifiable hepatic CYP3A5, unlike the remaining subjects, who were genotyped $C Y P 3 A 5^{*} 3 / * 3$ and did not express detectable CYP3A5. Of note, no intraindividual correlations were evident between the intestine and liver with respect to CYP3A4 expression, Pgp expression, or measured CYP3A4 catalytic activities (verapamil $N$-dealkylation and $N$-demethylation).

Similarly, Ulvestad et al. (2013) investigated the correlation between gut and liver OATP1B1, Pgp, and CYP3A4 expression and the $\mathrm{PK}$ of atorvastatin. In this instance, 21 patients with obesity were consented for paired biopsies (liver and intestinal segments) and $S L C O 1 B 1$ genotyping. The authors reported that $\sim 30 \%$ of the variation in oral clearance of atorvastatin could be ascribed to hepatic OATP1B1 protein expression. Subjects carrying the SLCO1B1 c.521C variant allele exhibited $45 \%$ lower atorvastatin oral clearance, and there was no association between the hepatic and intestinal expression of Pgp and CYP3A4 and the PK of atorvastatin.

At the time of writing, we became aware of the report by Krogstad et al. (2020). The authors were able to obtain matched liver and jejunal biopsy samples from CYP genotyped patients with obesity ( $n=20$ subjects). Both gut and liver microsomes were prepared, and various CYP activities were measured (CYP3A-dependent midazolam 1' hydroxylase, CYP2D6-dependent bufuralol 1-hydroxylase, CYP2C19-dependent mephenytoin 4-hydroxylase, CYP2C9dependent diclofenac 4-hydroxylase, CYP2C8-dependent amodiaquine $N$-demethylase, CYP2B6-dependent bupropion 6-hydroxylase, and CYP1A2-dependent phenacetin $O$-deethylase). CYP activity in each gut microsomal preparation was compared with its matched liver counterpart, and it was possible to obtain correlation coefficients for each CYP form (gut vs. liver) and across CYP forms (liver and gut). Because the subjects were genotyped, it was also possible to compare liver (e.g., $C Y P 1 A 2 * 1 / * 1$ vs. $C Y P 1 A 2 * 1 F / * 1 F, C Y P 2 C 9 * 1 / * 1$ vs. $C Y P 2 C 9 * 1 / * 2, \quad C Y P 2 C 19 * 1 / * 1$ vs. $C Y P 2 C 19 * 1 / * 2$, and $C Y P 2 D 6^{*} 1 / * 1$ vs. $C Y P 2 D 6^{*} 5 / *^{*}$ ) and gut (e.g., $C Y P 2 D 6^{*} 1 /$ $* 1$ vs. $C Y P 2 D 6 * 5 / * 5$ and $C Y P 2 C 9 * 1 / * 1$ vs. $C Y P 2 C 9 * 1 / * 2$ ) microsomal CYP activity for subjects carrying different alleles.
Multiple Intestinal Segments. We are aware of two groups that have described tissue profiling of different human intestine segments. Focused on studying the gut expression of four human CYPs (CYP2C8, CYP2E1, CYP3A4, and CYP3A5), Bergheim et al. (2005) were able to obtain biopsies from the ascending, descending, and sigmoid colon of test subjects. Although extensive interindividual variability was found for the expression of the four CYPs, the authors concluded that the expression of CYP2C8 in the ascending colon (vs. the sigmoid colon) and contrasted it with CYP2E1 and CYP3A5 mRNA expression. Likewise, Meier et al. (2007) were able to consent 10 healthy subjects to biopsies of five intestinal segments; duodenum, ileum, ascending colon, transverse colon, and descending colon. The samples were subjected to mRNA expression profiling, and it was possible to obtain data regarding the regional distribution of 15 different SLCs along the human intestinal tract. It was found that some of the SLCs were more or less expressed in all gut segments (e.g., OATP2B1, organic zwitterion/cation transporters 1 and 2 , and equilibrative nucleoside transporter 1), whereas others were more highly expressed in the duodenum and ileum (e.g., apical sodium-dependent bile acid transporter, peptide transporter 1, serotonin transporter, and concentrative nucleoside transporters 1 and 2).

\section{Advent of Liquid Biopsy}

To date, the concept of liquid biopsy, which involves the profiling of biofluids for solid organ- or tumor-specific markers, has gained traction in the field of oncology (Mader and Pantel, 2017). However, as previously described, it is envisioned that liquid biopsy methods will also be applied in support of ADME-related studies (Rodrigues and Rowland, 2019). For example, liquid biopsy would involve the use of validated methods to obtain global or tissue-specific preparations of cargo-laden (e.g., protein, mRNA, miR) nanovesicles (exosomes) from human blood (Fig. 1; Supplemental Figs. 1 and 2). Upon isolation, nanovesicle cargo would be profiled for drug-metabolizing enzyme expression (mRNA, protein) and activity. Likewise, SLC and ABC transporter expression could be determined. As in the case of conventional tissue biopsy samples, liquid biopsy samples could support both ex vivo (e.g., pre- vs. postdrug) and in vitro studies. Generation of such multiorgan liquid biopsy data in larger numbers of subjects and at multiple time points in a phase 1 study would provide a richer data set to support the PBPK modeling of NCEs. Importantly, the ability to obtain preparations of exosomes from blood and urine will greatly facilitate protocol review and study subject consenting (Table 1).

As described by Rodrigues and Rowland (2019) and summarized in Table 1 , there are some challenges when it comes to the deployment of exosome-based liquid biopsy methods. For example, most researchers are not familiar with exosome isolation protocols (e.g., size exclusion, precipitation, membrane affinity, and immunocapture), exosome characterization, handling, and storage. In particular, because of extracellular vesicle heterogeneity in various biofluids, preparations of exosomes require characterization and verification by microscopic methods (e.g., transmission electron microscopy), size analysis (e.g., nanoparticle tracking; diameter $\geq 30$ to $\sim 100 \mathrm{~nm}$ ) and immunoquantitation of exosome-enriched marker proteins (e.g., tumor susceptibility 
gene 101 programmed cell death 6-interacting protein and cluster of differentiation 63,9 , and 81 ). In addition, the purity of the exosome preparation needs to be defined (e.g., ratio of particle number to total protein $>3 \times 10^{10}$ particles per microgram protein). Beyond exosome sample characterization, handling, and storage, presently it is not known how circulating populations of exosomes relate to their organ of origin or how data obtained with exosomes are integrated into PBPK models (Table 1). Despite the challenges, exosome-based liquid biopsy approaches have great potential, and some examples of their application are described in the following sections.

\section{Literature Examples Describing the Use of an Exosome-Based Liquid Biopsy Approach}

Profiling of Human Blood-Derived Global Exosomes to Study Induction of CYP3A4 after Rifampicin Dosing. Rowland et al. (2019) were able to deploy a commercially available membrane affinity spin column kit to isolate total plasma exosomes (transmission electron microscopy, nanoparticle tracking, and tumor susceptibility gene 101 qualified) from rifampicin-dosed (300 $\mathrm{mg}$ daily for 7 days) subjects $(n=6)$. The same subjects also received oral midazolam (1 mg) pre- and postrifampicin. For the first time, it was reported that exosomal CYP3A4 expression (mRNA and protein) is well correlated with the nicotinamide adenine dinucleotide phosphate-dependent exosomal CYP3A4 activity (midazolam 1'-hydroxylase) following the addition of a poreforming agent (alamethicin). Importantly, rifampicin brought about an increase in exosomal CYP3A4 mRNA expression (up to 41-fold), protein expression (up to 3.5-fold), and activity (up to 2.4-fold). An excellent correlation between the changes in exosomal CYP3A4 mRNA ( $\mathrm{r} 2=0.882)$, protein $(\mathrm{r} 2=0.917)$, and activity $(\mathrm{r} 2=0.828)$ with midazolam oral clearance was also reported. In addition, exosomal midazolam $1^{\prime}$ hydroxylase activity was inhibited $(\sim 95 \%)$ by the established CYP3A4-selective inhibitor CYP3cide (1-methyl-3-[1-methyl5-(4-methylphenyl)-1H-pyrazol-4-yl]-4-[(3S)-3-piperidin-1ylpyrrolidin-1-yl]-1H-pyrazolo[3,4-day]pyrimidine). The same exosome preparations were also subjected to targeted proteomic analysis, and peptides for numerous additional human CYPs (CYP1A2, CYP2B6, CYP2C8, CYP2C9, CYP2C19, CYP2D6, CYP2E1, CYP2J2, CYP3A5), CYP reductase, and UGTs (UGT1A1, UGT1A3, UGT1A4, UGT1A6, UGT1A9, UGT2B4, UGT2B7, UGT2B10, and UGT2B15) were detected. For the latter, exosomes were fortified with cofactor (uridine 5 '-diphosphoglucuronic acid), and 4-methylumbelliferone glucuronidation was measured with a single $\mathrm{K}_{\mathrm{m}}$ (concentration of 4-methylumbelliferone rendering half-maximal rate of glucuronidation), similar to that obtained for cofactor-fortified and alamethicin-treated human liver microsomes. It is envisioned that preparations of plasma-derived global exosomes, such as the ones described above, could be further subjected to immunocapture protocols to enable the isolation of tissuespecific exosomes. The development of such protocols will be important for drug-metabolizing enzymes that reside in both the gut and liver (e.g., CYP3A4).

Human Plasma-Derived Intestinal Exosomes to Support BCRP Expression Profiling. As described by Gotanda et al. (2016), it is possible to correlate the expression of intestinal miR-328, which modulates BCRP expression, and the AUC of an orally dosed BCRP substrate (sulfasalazine) across 33 different subjects. The authors come to such a conclusion because they were able to isolate antigen 33 (A33)-enriched plasma exosomes using an anti-A33 antibody immunocapture approach. Compared with other human tissues, A33 is highly expressed in intestinal epithelial cells. Therefore, intestinal epithelial cell-derived plasma exosomes are expected to express high levels of surface A33. Following their immunocapture procedure, the authors confirmed the isolation of exosomes (immunoblotting with antibodies to cluster of differentiation 9 and A33) and showed that their preparations presented elevated expression of two miRs known to be enriched in the human intestine (miR-192 and miR-215 vs. liver selective miR-122). Subsequently, the authors described a correlation $(r=0.346, P<0.049)$ between the plasma AUC of sulfasalazine and miR-328 expression levels in their gut-derived exosome preparations. Of note, a weaker correlation ( $r=0.157, P=0.328$ ) was obtained for plasma-derived (global) exosomes prior to immunocapture. In the future, it is envisioned that such a study would incorporate ABCG2 genotype, exosome BCRP protein expression, and a consideration of hepatic miR-328 expression and its impact on the AUC of sulfasalazine following an oral dose.

Isolation of Global Exosomes from Human Urine to Support SLC22A5 Activity Profiling. Console et al. (2018) were able to prepare exosomes from human urine to support in vitro transporter studies with carnitine/organic cation transporter 2 (SLC22A5). SLC22A5 is known to mediate the sodium-dependent transport of carnitine and is highly expressed on the apical membranes of renal proximal tubule epithelial cells. In this instance, the authors isolated exosomes from a urine sample by ultracentrifugation and confirmed their identity by immunoblotting with an antibody to tumor susceptibility gene 101 and cluster of differentiation 9. The authors were also able to detect SLC22A5 expression by immunoblotting, reconstitute the isolated exosomes with proteoliposomes, and measure uptake of radiolabeled carnitine in the presence of sodium. Because exosomes are largely formed via an intracellular budding process involving multivesicular bodies followed by exocytosis, it is assumed that urinary exosomes are reflective of the apical membranes of renal proximal tubule epithelial cells and enriched for SLC22A5. Whether plasma-derived exosomes contain functional basolateral kidney (organic anion or cation) and liver (e.g., OATP) transporters is not known.

\section{Conclusions}

Based on a review of the literature, it is evident that there are numerous examples of clinical studies leveraging tissue biopsy, albeit with relatively small numbers of subjects, to support the study of drug metabolism, transport, and PK. It is apparent that tissue biopsy data can be useful when testing hypotheses, conducting modeling and simulation exercises, assessing drug interactions, studying phenotype-genotype associations, and evaluating the impact of disease and ontogeny on the tissue expression and activity profiles of different drug-metabolizing enzymes and transporters.

Increasingly, however, there will likely be greater demand for multiple single-tissue biopsies to study drug interaction time courses, the impact of disease over time, or drug dose level dependency in a single individual. With growing interest 
in remote sensing (interorgan communication) and how multiorgan axes drive endogenous compound (endobiotic) PKADME processes, govern homeostasis, and respond to disease and drug interactions, it is highly likely that the demand for multiorgan biopsies will also increase (Wu et al., 2011; Bush et al., 2017; Fu and Cui, 2017; Momper and Nigam, 2018; Rodrigues and Rowland, 2019). Ethically, this would prove challenging when studying subjects that do not classify as "normal healthy volunteers" (e.g., diseased, organ impaired, pediatric, elderly, and pregnant women). To meet such a need, it is envisioned that PK-ADME researchers, PBPK modelers, and clinical pharmacologists will turn to "liquid biopsy" approaches (Rodrigues and Rowland, 2019; Rowland et al., 2019). In the long run, the greater availability of multiorganderived, banked, and profiled liquid biopsy samples from large numbers of individuals, representative of different populations, could greatly support the translation of PK-ADME (phase 1 study) data obtained with young male volunteers who are normal and healthy.

\section{Authorship Contributions}

Wrote or contributed to the writing of the manuscript: Rodrigues, Rowland.

\section{References}

Aiba T, Susa M, Fukumori S, and Hashimoto Y (2005) The effects of culture conditions on CYP3A4 and MDR1 mRNA induction by 1alpha,25-dihydroxyvitamin $\mathrm{D}(3)$ in human intestinal cell lines, Caco-2 and LS180. Drug Metab Pharmacokinet 20: $268-274$.

Almond LM, Mukadam S, Gardner I, Okialda K, Wong S, Hatley O, Tay S, RowlandYeo K, Jamei M, Rostami-Hodjegan A, et al. (2016) Prediction of drug-drug interactions arising from CYP3A induction using a physiologically based dynamic model. Drug Metab Dispos 44:821-832.

Asaumi R, Menzel K, Lee W, Nunoya KI, Imawaka H, Kusuhara H, and Sugiyama Y (2019) Expanded physiologically-based pharmacokinetic model of rifampicin for predicting interactions with drugs and an endogenous biomarker via complex mechanisms including organic anion transporting polypeptide $1 \mathrm{~B}$ induction. $C P T$ Pharmacometrics Syst Pharmacol 8:845-857.

Asher GN, Fallon JK, and Smith PC (2016) UGT concentrations in human rectal tissue after multidose, oral curcumin. Pharmacol Res Perspect 4:e00222.

Bergheim I, Bode C, and Parlesak A (2005) Distribution of cytochrome P450 2C, 2E1, 3A4, and 3A5 in human colon mucosa. BMC Clin Pharmacol 5:4.

Björkhem-Bergman L, Bergström H, Johansson M, Parini P, Eriksson M, Rane A, and Ekström L (2013) Atorvastatin treatment induces uptake and efflux transporters in human liver. Drug Metab Dispos 41:1610-1615.

Brueck S, Bruckmueller H, Wegner D, Busch D, Martin P, Oswald S, Cascorbi I, and Siegmund W (2019) Transcriptional and post-transcriptional regulation of duodenal P-glycoprotein and MRP2 in healthy human subjects after chronic treatment with rifampin and carbamazepine. Mol Pharm 16:3823-3830.

Brussee JM, Yu H, Krekels EHJ, Palić S, Brill MJE, Barrett JS, Rostami-Hodjegan A de Wildt SN, and Knibbe CAJ (2018) Characterization of intestinal and hepatic CYP3A-mediated metabolism of midazolam in children using a physiological population pharmacokinetic modelling approach. Pharm Res 35:182.

Buchthal J, Grund KE, Buchmann A, Schrenk D, Beaune P, and Bock KW (1995) Induction of cytochrome P4501A by smoking or omeprazole in comparison with UDP-glucuronosyltransferase in biopsies of human duodenal mucosa. Eur J Clin Pharmacol 47:431-435.

Bush KT, Wu W, Lun C, and Nigam SK (2017) The drug transporter OAT3 (SLC22A8) and endogenous metabolite communication via the gut-liver-kidney axis. $J$ Biol Chem 292:15789-15803.

Console L, Scalise M, Tonazzi A, Giangregorio N, and Indiveri C (2018) Characterization of exosomal SLC22A5 (OCTN2) carnitine transporter. Sci Rep 8:3758.

Englund G, Jacobson A, Rorsman F, Artursson P, Kindmark A, and Rönnblom A (2007) Efflux transporters in ulcerative colitis: decreased expression of BCRP (ABCG2) and Pgp (ABCB1). Inflamm Bowel Dis 13:291-297.

Erdmann P, Bruckmueller H, Martin P, Busch D, Haenisch S, Müller J, WiechowskaKozlowska A, Partecke LI, Heidecke CD, Cascorbi I, et al. (2019) Dysregulation of mucosal membrane transporters and drug-metabolizing enzymes in ulcerative colitis. J Pharm Sci 108:1035-1046.

Fakhoury M, Litalien C, Medard Y, Cavé H, Ezzahir N, Peuchmaur M, and JacqzAigrain E (2005) Localization and mRNA expression of CYP3A and P-glycoprotein in human duodenum as a function of age. Drug Metab Dispos 33:1603-1607.

Fontana RJ, Lown KS, Paine MF, Fortlage L, Santella RM, Felton JS, Knize MG, Greenberg A, and Watkins PB (1999) Effects of a chargrilled meat diet on expression of CYP3A, CYP1A, and P-glycoprotein levels in healthy volunteers. Gastroenterology 117:89-98.

Fromm MF, Kauffmann HM, Fritz P, Burk O, Kroemer HK, Warzok RW, Eichelbaum M, Siegmund W, and Schrenk D (2000) The effect of rifampin treatment on in testinal expression of human MRP transporters. Am J Pathol 157:1575-1580.
Fu ZD and Cui JY (2017) Remote sensing between liver and intestine: importance of microbial metabolites. Curr Pharmacol Rep 3:101-113.

Ged C, Rouillon JM, Pichard L, Combalbert J, Bressot N, Bories P, Michel H, Beaune $\mathrm{P}$, and Maurel P (1989) The increase in urinary excretion of 6 beta-hydroxycortisol as a marker of human hepatic cytochrome P450IIIA induction. Br J Clin Pharmacol 28:373-387.

Giessmann T, May K, Modess C, Wegner D, Hecker U, Zschiesche M, Dazert P, Grube M, Schroeder E, Warzok R, et al. (2004a) Carbamazepine regulates intestinal P-glycoprotein and multidrug resistance protein MRP2 and influences disposition of talinolol in humans. Clin Pharmacol Ther 76:192-200.

Giessmann T, Modess C, Hecker U, Zschiesche M, Dazert P, Kunert-Keil C, Warzok R, Engel G, Weitschies W, Cascorbi I, et al. (2004b) CYP2D6 genotype and induction of intestinal drug transporters by rifampin predict presystemic clearance of carvedilol in healthy subjects. Clin Pharmacol Ther 75:213-222.

Glaeser H, Drescher S, Eichelbaum M, and Fromm MF (2005) Influence of rifampicin on the expression and function of human intestinal cytochrome P450 enzymes. Br J Clin Pharmacol 59:199-206.

Gorski JC, Jones DR, Haehner-Daniels BD, Hamman MA, O'Mara EM Jr, and Hall SD (1998) The contribution of intestinal and hepatic CYP3A to the interaction between midazolam and clarithromycin. Clin Pharmacol Ther 64:133-143.

Gorski JC, Jones DR, Wrighton SA, and Hall SD (1994) Characterization of dextromethorphan N-demethylation by human liver microsomes. Contribution of the cytochrome P450 3A (CYP3A) subfamily. Biochem Pharmacol 48:173-182.

Gotanda K, Hirota T, Saito J, Fukae M, Egashira Y, Izumi N, Deguchi M, Kimura M, Matsuki S, Irie S, et al. (2016) Circulating intestine-derived exosomal miR-328 in plasma, a possible biomarker for estimating BCRP function in the human intestines. Sci Rep 6:32299.

Greiner B, Eichelbaum M, Fritz P, Kreichgauer HP, von Richter O, Zundler J, and Kroemer HK (1999) The role of intestinal P-glycoprotein in the interaction of digoxin and rifampin. $J$ Clin Invest 104:147-153.

Guo H, Liu C, Li J, Zhang M, Hu M, Xu P, Liu L, and Liu X (2013) A mechanistic physiologically based pharmacokinetic-enzyme turnover model involving both intestine and liver to predict CYP3A induction-mediated drug-drug interactions. J Pharm Sci 102:2819-2836.

Haenisch S, May K, Wegner D, Caliebe A, Cascorbi I, and Siegmund W (2008) Influence of genetic polymorphisms on intestinal expression and rifampicin-type induction of ABCC2 and on bioavailability of talinolol. Pharmacogenet Genomics 18: 357-365.

Hanke N, Frechen S, Moj D, Britz H, Eissing T, Wendl T, and Lehr T (2018) PBPK models for CYP3A4 and P-gp DDI prediction: a modeling network of rifampicin, itraconazole, clarithromycin, midazolam, alfentanil, and digoxin. CPT Pharmacometrics Syst Pharmacol 7:647-659.

Haslam IS, Jones K, Coleman T, and Simmons NL (2008) Rifampin and digoxin induction of MDR1 expression and function in human intestinal (T84) epithelial cells. Br J Pharmacol 154:246-255.

Jones DR, Gorski JC, Haehner BD, O'Mara EM Jr, and Hall SD (1996) Determination of cytochrome P450 3A4/5 activity in vivo with dextromethorphan N-demethylation. Clin Pharmacol Ther 60:374-384.

Joy MS, Hogan SL, Thompson BD, Finn WF, and Nickeleit V (2007) Cytochrome P450 3 A5 expression in the kidneys of patients with calcineurin inhibitor nephrotoxicity. Nephrol Dial Transplant 22:1963-1968.

Ke AB, Nallani SC, Zhao P, Rostami-Hodjegan A, Isoherranen N, and Unadkat JD (2013) A physiologically based pharmacokinetic model to predict disposition of CYP2D6 and CYP1A2 metabolized drugs in pregnant women. Drug Metab Dispos 41:801-813.

Kim JH, Sherman ME, Curriero FC, Guengerich FP, Strickland PT, and Sutter TR (2004) Expression of cytochromes P450 1A1 and 1B1 in human lung from smokers, non-smokers, and ex-smokers. Toxicol Appl Pharmacol 199:210-219.

Kis O, Sankaran-Walters S, Hoque MT, Walmsley SL, Dandekar S, and Bendayan R (2016) HIV-1 alters intestinal expression of drug transporters and metabolic enzymes: implications for antiretroviral drug disposition. Antimicrob Agents Chemother 60:2771-2781.

Krogstad V, Peric A, Robertsen I, Kringen MK, Wegler C, Angeles PC, Hjelmesæth J, Karlsson C, Andersson S, Artursson P, et al. (2020) A comparative analysis of cytochrome P450 activities in paired liver and small intestinal samples from patients with obesity. Drug Metab Dispos 48:8-17.

Krogstad V, Vethe NT, Robertsen I, Hasvold G, Ose AD, Hermann M, Andersen AM, Chan J, Skauby M, Svensson MHS, et al. (2018) Determination of tacrolimus concentration and protein expression of P-glycoprotein in single human renal core biopsies. Ther Drug Monit 40:292-300.

Lang CC, Brown RM, Kinirons MT, Deathridge MA, Guengerich FP, Kelleher D, O'Briain DS, Ghishan FK, and Wood AJ (1996) Decreased intestinal CYP3A in celiac disease: reversal after successful gluten-free diet: a potential source of interindividual variability in first-pass drug metabolism. Clin Pharmacol Ther $\mathbf{5 9}$ $41-46$.

Lefor AT and Flowers JL (1994) Laparoscopic wedge biopsy of the liver. J Am Coll Surg 178:307-308.

Li AP, Alam N, Amaral K, Ho MD, Loretz C, Mitchell W, and Yang Q (2018) Cryopreserved human intestinal mucosal epithelium: a novel in vitro experimenta system for the evaluation of enteric drug metabolism, cytochrome P450 induction, and enterotoxicity. Drug Metab Dispos 46:1562-1571.

Lown KS, Kolars JC, Thummel KE, Barnett JL, Kunze KL, Wrighton SA, and Watkins PB (1994) Interpatient heterogeneity in expression of CYP3A4 and CYP3A5 in small bowel. Lack of prediction by the erythromycin breath test. Drug Metab Dispos 22: 947-955.

Maass C, Stokes CL, Griffith LG, and Cirit M (2017) Multi-functional scaling methodology for translational pharmacokinetic and pharmacodynamic applications using integrated microphysiological systems (MPS). Integr Biol 9:290-302.

Mader S and Pantel K (2017) Liquid biopsy: current status and future perspectives. Oncol Res Treat 40:404-408. 
Marschall HU, Wagner M, Zollner G, Fickert P, Diczfalusy U, Gumhold J, Silbert D, Fuchsbichler A, Benthin L, Grundström R, et al. (2005) Complementary stimulation of hepatobiliary transport and detoxification systems by rifampicin and ursodeoxycholic acid in humans. Gastroenterology 129:476-485.

McConnachie L, Bodor M, Kowdley K, Levy A, Tung B, Thummel K, Phillips B, Bajpai M, Chi V, Esmay JD, et al. (2004) Human liver cytochrome P450 2D6 genotype, fulllength messenger ribonucleic acid, and activity assessed with a novel cytochrome P450 2D6 substrate. Clin Pharmacol Ther 75:282-297.

Meier Y, Eloranta JJ, Darimont J, Ismair MG, Hiller C, Fried M, Kullak-Ublick GA, and Vavricka SR (2007) Regional distribution of solute carrier mRNA expression along the human intestinal tract. Drug Metab Dispos 35:590-594.

Miyauchi E, Tachikawa M, Declèves X, Uchida Y, Bouillot JL, Poitou C, Oppert JM, Mouly S, Bergmann JF, Terasaki T, et al. (2016) Quantitative atlas of cytochrome P450, UDP-glucuronosyltransferase, and transporter proteins in jejunum of morbidly obese subjects. Mol Pharm 13:2631-2640.

Momper JD and Nigam SK (2018) Developmental regulation of kidney and liver solute carrier and ATP-binding cassette drug transporters and drug metabolizing enzymes: the role of remote organ communication. Expert Opin Drug Metab Toxicol 14: 561-570.

Mooij MG, Schwarz UI, de Koning BA, Leeder JS, Gaedigk R, Samsom JN, Spaans E van Goudoever JB, Tibboel D, Kim RB, et al. (2014) Ontogeny of human hepatic and intestinal transporter gene expression during childhood: age matters. Drug Metab Dispos 42:1268-1274.

Mouly S, Lown KS, Kornhauser D, Joseph JL, Fiske WD, Benedek IH, and Watkins PB (2002) Hepatic but not intestinal CYP3A4 displays dose-dependent induction by efavirenz in humans. Clin Pharmacol Ther 72:1-9.

Mouly SJ, Matheny C, Paine MF, Smith G, Lamba J, Lamba V, Pusek SN, Schuetz EG, Stewart PW, and Watkins PB (2005) Variation in oral clearance of saquinavir is predicted by CYP3A5* 1 genotype but not by enterocyte content of cytochrome P450 3A5. Clin Pharmacol Ther 78:605-618.

Nakai K, Tanaka H, Hanada K, Ogata H, Suzuki F, Kumada H, Miyajima A, Ishida S, Sunouchi M, Habano W, et al. (2008) Decreased expression of cytochromes P450 $1 \mathrm{~A} 2,2 \mathrm{E} 1$, and $3 \mathrm{~A} 4$ and drug transporters $\mathrm{Na}^{+}$-taurocholate-cotransporting polypeptide, organic cation transporter 1 , and organic anion-transporting peptide-C correlates with the progression of liver fibrosis in chronic hepatitis C patients. Drug Metab Dispos 36:1786-1793.

Oscarson M, Burk O, Winter S, Schwab M, Wolbold R, Dippon J, Eichelbaum M, and Meyer UA (2007) Effects of rifampicin on global gene expression in human small intestine. Pharmacogenet Genomics 17:907-918.

Oscarson M, Zanger UM, Rifki OF, Klein K, Eichelbaum M, and Meyer UA (2006) Transcriptional profiling of genes induced in the livers of patients treated with carbamazepine. Clin Pharmacol Ther 80:440-456.

Osman-Ponchet H, Boulai A, Kouidhi M, Sevin K, Alriquet M, Gaborit A, Bertino B Comby P, and Ruty B (2014) Characterization of ABC transporters in human skin. Drug Metabol Drug Interact 29:91-100.

Oswald S, Meyer zu Schwabedissen HE, Nassif A, Modess C, Desta Z, Ogburn ET, Mostertz J, Keiser M, Jia J, Hubeny A, et al. (2012) Impact of efavirenz on intestinal metabolism and transport: insights from an interaction study with ezetimibe in healthy volunteers. Clin Pharmacol Ther 91:506-513.

Otuya DO, Verma Y, Farrokhi H, Higgins L, Rosenberg M, Damman C, and Tearney GJ (2018) Non-endoscopic biopsy techniques: a review. Expert Rev Gastroenterol Hepatol 12:109-117.

Padoin AV, Mottin CC, Moretto M, Berleze D, Kupski C, Glock L, Reichel CL, da Silva VD, and da Silva JB (2006) A comparison of wedge and needle hepatic biopsy in open bariatric surgery. Obes Surg 16:178-182.

Pan X, Ning M, and Jeong H (2017) Transcriptional regulation of CYP2D6 expression. Drug Metab Dispos 45:42-48.

Pelkonen O, Pasanen M, Kuha H, Gachalyi B, Kairaluoma M, Sotaniemi EA, Park SS, Friedman FK, and Gelboin HV (1986) The effect of cigarette smoking on 7ethoxyresorufin O-deethylase and other monooxygenase activities in human liver: analyses with monoclonal antibodies. Br J Clin Pharmacol 22:125-134.

Perrot N, Nalpas B, Yang CS, and Beaune PH (1989) Modulation of cytochrome P450 isozymes in human liver, by ethanol and drug intake. Eur J Clin Invest 19:549-555.

Pinto AG, Horlander J, Chalasani N, Hamman M, Asghar A, Kolwankar D, and Hall SD (2005b) Diltiazem inhibits human intestinal cytochrome P450 3A (CYP3A) ac tivity in vivo without altering the expression of intestinal mRNA or protein. $B r$ $J$ Clin Pharmacol 59:440-446.

Pinto AG, Wang YH, Chalasani N, Skaar T, Kolwankar D, Gorski JC, Liangpunsaku S, Hamman MA, Arefayene M, and Hall SD (2005a) Inhibition of human intestina wall metabolism by macrolide antibiotics: effect of clarithromycin on cytochrome P450 3A4/5 activity and expression. Clin Pharmacol Ther 77:178-188.

Quinney SK, Malireddy SR, Vuppalanchi R, Hamman MA, Chalasani N, Gorski JC, and Hall SD (2013) Rate of onset of inhibition of gut-wall and hepatic CYP3A by clarithromycin. Eur J Clin Pharmacol 69:439-448.

Quinney SK, Zhang X, Lucksiri A, Gorski JC, Li L, and Hall SD (2010) Physiologically based pharmacokinetic model of mechanism-based inhibition of CYP3A by clarithromycin. Drug Metab Dispos 38:241-248.

Rae JM, Johnson MD, Lippman ME, and Flockhart DA (2001) Rifampin is a selective, pleiotropic inducer of drug metabolism genes in human hepatocytes: studies with cDNA and oligonucleotide expression arrays. J Pharmacol Exp Ther 299:849-857.
Rodrigues D and Rowland A (2019) From endogenous compounds as biomarkers to plasma-derived nanovesicles as liquid biopsy; has the golden age of translational pharmacokinetics-absorption, distribution, metabolism, excretion-drug-drug interaction science finally arrived? Clin Pharmacol Ther 105:1407-1420.

Rowland A, Ruanglertboon W, van Dyk M, Wijayakumara D, Wood LS, Meech R, Mackenzie PI, Rodrigues AD, Marshall JC, and Sorich MJ (2019) Plasma extracellular nanovesicle (exosome)-derived biomarkers for drug metabolism pathways: a novel approach to characterize variability in drug exposure. $\mathrm{Br}$ J Clin Pharmacol 85:216-226.

Sager JE, Tripathy S, Price LS, Nath A, Chang J, Stephenson-Famy A, and Isoherranen $\mathrm{N}$ (2017) In vitro to in vivo extrapolation of the complex drug-drug interaction of bupropion and its metabolites with CYP2D6; simultaneous reversible inhibition and CYP2D6 downregulation. Biochem Pharmacol 123:85-96.

Scheer N, Kapelyukh Y, Rode A, Oswald S, Busch D, McLaughlin LA, Lin D, Henderson CJ, and Wolf CR (2015) Defining human pathways of drug metabolism in vivo through the development of a multiple humanized mouse model. Drug Metab Dispos 43:1679-1690.

Schmider J, Greenblatt DJ, Fogelman SM, von Moltke LL, and Shader RI (1997) Metabolism of dextromethorphan in vitro: involvement of cytochromes P450 2D6 and 3A3/4, with a possible role of 2E1. Biopharm Drug Dispos 18:227-240.

Smith GB, Harper PA, Wong JM, Lam MS, Reid KR, Petsikas D, and Massey TE (2001) Human lung microsomal cytochrome P4501A1 (CYP1A1) activities: impact of smoking status and CYP1A1, aryl hydrocarbon receptor, and glutathione S-transferase M1 genetic polymorphisms. Cancer Epidemiol Biomarkers Prev 10: 839-853.

Thum T, Erpenbeck VJ, Moeller J, Hohlfeld JM, Krug N, and Borlak J (2006) Expression of xenobiotic metabolizing enzymes in different lung compartments of smokers and nonsmokers. Environ Health Perspect 114:1655-1661.

Ulvestad M, Skottheim IB, Jakobsen GS, Bremer S, Molden E, Asberg A, Hjelmesæth J, Andersson TB, Sandbu R, and Christensen H (2013) Impact of OATP1B1, MDR1, and CYP3A4 expression in liver and intestine on interpatient pharmacokinetic variability of atorvastatin in obese subjects. Clin Pharmacol Ther 93:275-282.

Varela NM, Quiñones LA, Orellana M, Poniachik J, Csendes A, Smok G, Rodrigo R, Cáceres DD, and Videla LA (2008) Study of cytochrome P450 2E1 and its allele variants in liver injury of nondiabetic, nonalcoholic steatohepatitis obese women. Biol Res 41:81-92.

von Richter O, Burk O, Fromm MF, Thon KP, Eichelbaum M, and Kivistö KT (2004) Cytochrome P450 3A4 and P-glycoprotein expression in human small intestinal enterocytes and hepatocytes: a comparative analysis in paired tissue specimens. Clin Pharmacol Ther 75:172-183.

Wang YI, Carmona C, Hickman JJ, and Shuler ML (2018) Multiorgan microphysiological systems for drug development: strategies, advances, and challenges. Adv Healthc Mater 7 Available from: 10.1002/adhm.201701000.

Waring RH (2020) Cytochrome P450: genotype to phenotype. Xenobiotica 50:9-18. Weiß F, Hammer HS, Klein K, Planatscher H, Zanger UM, Norén A, Wegler C, Artursson P, Joos TO, and Poetz O (2018) Direct quantification of cytochromes P450 and drug transporters-a rapid, targeted mass spectrometry-based immunoassay panel for tissues and cell culture lysates. Drug Metab Dispos 46:387-396.

Weiss J, Herzog M, König S, Storch CH, Ketabi-Kiyanvash N, and Haefeli WE (2009) Induction of multiple drug transporters by efavirenz. J Pharmacol Sci 109:242-250.

Westphal K, Weinbrenner A, Zschiesche M, Franke G, Knoke M, Oertel R, Fritz P, von Richter O, Warzok R, Hachenberg T, et al. (2000) Induction of P-glycoprotein by rifampin increases intestinal secretion of talinolol in human beings: a new type of drug/drug interaction. Clin Pharmacol Ther 68:345-355.

Wilson A, Urquhart BL, Ponich T, Chande N, Gregor JC, Beaton M, and Kim RB (2019) Crohn's disease is associated with decreased CYP3A4 and P-glycoprotein protein expression. Mol Pharm 16:4059-4064.

Woolsey SJ, Mansell SE, Kim RB, Tirona RG, and Beaton MD (2015) CYP3A activity and expression in nonalcoholic fatty liver disease. Drug Metab Dispos 43:1484-1490.

Wu W, Dnyanmote AV, and Nigam SK (2011) Remote communication through solute carriers and ATP binding cassette drug transporter pathways: an update on the remote sensing and signaling hypothesis. Mol Pharmacol 79:795-805.

Yamazaki S, Costales C, Lazzaro S, Eatemadpour S, Kimoto E, and Varma MV (2019) Physiologically-based pharmacokinetic modeling approach to predict rifampinmediated intestinal P-glycoprotein induction. CPT Pharmacometrics Syst Pharmacol 8:634-642.

Zhang X, Quinney SK, Gorski JC, Jones DR, and Hall SD (2009) Semiphysiologically based pharmacokinetic models for the inhibition of midazolam clearance by diltiazem and its major metabolite. Drug Metab Dispos 37:1587-1597.

Zollner G, Fickert P, Zenz R, Fuchsbichler A, Stumptner C, Kenner L, Ferenci P, Stauber RE, Krejs GJ, Denk H, et al. (2001) Hepatobiliary transporter expression in percutaneous liver biopsies of patients with cholestatic liver diseases. Hepatology 33:633-646.

Address correspondence to: Dr. A. David Rodrigues, ADME Sciences, Medicine Design, Worldwide Research \& Development, Pfizer Inc., Eastern Point Road, Bldg 220/002/2565, Mail Stop 8220-2439, Pfizer Inc., Groton, CT 06340. E-mail: a.david.rodrigues@pfizer.com 